\title{
Stefano Elia*
}

Maria Giuffrida*

Lucia Piscitello**

\section{DOES E-COMMERCE FACILITATE OR COMPLICATE SMEs' INTERNATIONALISATION?}

The effects of the digital revolution on the internationalisation process of SMEs are yet to be addressed. This empirical evidence drawn from a recent survey on Italian companies operating in the food and fashion industries shows that only a few Italian companies use e-commerce to grow in foreign markets: SMEs still face traditional obstacles and new e-commerce-specific barriers arise, such as the lack of knowledge concerning foreign digital markets, the legal requirements for e-commerce and the lack of knowledge concerning the appropriate digital channels or online payment systems.

\section{¿El comercio electrónico facilita o complica la internacionalización de las pymes?}

El efecto de la revolución digital ha sido escasamente abordado en la internacionalización de las pymes. Este artículo muestra que solo unas pocas empresas italianas en los sectores de la alimentación y la moda utilizan el comercio electrónico para la internacionalización. Las barreras son tanto tradicionales - los costes asociados a la logística y la adaptación a diferentes culturas - como las asociadas con el desconocimiento de los mercados digitales extranjeros, los requisitos legales para el comercio electrónico y el desconocimiento de los canales digitales o de los sistemas de pago en línea.

Keywords: digitalisation, SMEs, internationalisation.

Palabras clave: digitalización, pyme, internacionalización.

JEL: F23, L66, L67, L81.

\section{Introduction}

In recent years, the growing diffusion of high-speed internet and the advancement of electronic and mobile commerce technologies all over the world have contributed to the rise of Cross Border E-Commerce (CBEC). CBEC is the process of selling goods to consumers located in a foreign country by means of online channels,

\footnotetext{
* Politecnico di Milano.

** Politecnico di Milano y University of Reading.

DOI: https://doi.org/10.32796/ice.2019.909.6901
}

such as e-commerce websites, online retailers and marketplaces (Giuffrida et al., 2017a). Today, it accounts for as much as $30 \%$ of overall online commerce. The main drivers of this phenomenon are the world's biggest e-commerce markets (China, the US and the UK), where consumers are increasingly familiar with and willing to adopt technology to purchase goods and services both domestically and from abroad. CBEC is therefore an opportunity for both online merchants and traditional companies to expand their businesses overseas.

Players such as Alibaba, the major Chinese online marketplace, are revolutionising the retail industry by 
getting Chinese consumers more and more used to shopping online. The same is the case with Amazon and other top players in the Western economy. As consumers are becoming progressively more used to shopping online and having easy access to international brands, CBEC represents an opportunity today, but it could easily become a "must" in the near future, forcing traditional producers and retailers to adjust their business models (Ahlert et al., 2010).

However, a number of obstacles come into play as regards seizing this opportunity. In fact, several barriers still exist for the adoption of e-commerce by firms operating nationally (Walczuch et al., 2000; Kshetri, 2007) and additional difficulties, including linguistic, cultural, legal and infrastructural issues, are common inhibitors of e-commerce at an international level.

As these obstacles usually prevent initiating CBEC (Martens, 2013), correctly identifying barriers to CBEC represents a first step towards the configuration of appropriate strategies in order to overcome them.

This study aims to contribute to the debate on the role of information and communications technologies in fostering the internationalisation of firms (Alcácer et al., 2016) by focusing on the barriers and obstacles to CBEC (de la Torre and Moxon, 2001; Zaheer and Manrakhan, 2001; Piscitello and Sgobbi, 2003; 2004) experienced by Italian companies, especially SMEs. Specifically, we conduct an empirical analysis on a sample of Italian companies operating in the food and fashion industries, with a focus on two destination markets, i.e. China and the USA, which are of particular interest when it comes to the development of an e-commerce strategy (Forrester, 2018).

On the one hand, China has experienced significant growth of both its economy and the use of technologies in the past few years. With a 1,000 billion euro turnover, it has become one of the biggest Business to Consumer (B2C) e-commerce markets in the world (Forrester, 2018). On the other hand, the USA constitutes a more mature market and displays more limited growth rates; however, it is still among the largest B2C e-commerce markets in terms of value, and American consumers are typically used to online shopping.

The amount of B2C export transacted online by Italian companies is rather limited, as it represents just a few share points of the total Italian consumer goods export (Digital Export Observatory, 2019). Given the lack of studies specifically exploring the barriers facing Italian companies regarding the use of e-commerce as an export-enhancing tool, this study aims to address this gap. In particular, we conducted a survey to identify the main reasons for the limited adoption of e-commerce to sell abroad with respect to specific destination markets, i.e. China and the USA, as well as other non-specified destination markets. The responses show that $i$ ) some barriers are the same as for traditional "offline" internationalisation, while others are specific to CBEC; ii) some barriers are shared by large and small companies, while others apply mainly to the latter; iii) some barriers occur across countries while others are idiosyncratic to the Chinese and US markets.

This paper is organised as follows: section 2 provides an overview of current literature on B2C CBEC, with a focus on the typical impediments thereto. Section 3 illustrates the survey methodology and results, while section 4 presents the final discussion and conclusion.

\section{The role of e-commerce in SME's internationalisation: opportunities and barriers}

Data from the World Trade Organisation (WTO) show that, despite the financial crisis, the ratio of global trade of goods and services to GDP has increased significantly in the past decade, rising from $20 \%$ in 1995 to $30 \%$ in 2018 (WTO, 2018). This trend is even more marked if combined with another of the most significant recent phenomena, i.e. B2C e-commerce, which reached a global value of 2,500 billion euro in 2018 , growing by an average of $20 \%$ in the past few years (Forrester, 2018). 
This points to the potential future developments of this technology, which represents an opportunity for producers and retailers to grow locally as well as in new foreign markets (Premazzi et al., 2010). According to Qin et al. (2009), e-commerce could indeed act as a booster for international trade, since it allows one to improve efficiency by dematerialising most of the document-exchange processes related to transactions. Certain scholars had already perceived the potential benefits e-commerce could bring to global trade at the dawn of the 21st century, even before its actual establishment (Quelch and Klein, 1996; Fariselli et al., 1999). Nonetheless, despite an increasing interest in CBEC, the literature on e-internationalisation remains scant (de la Torre and Moxon, 2001; Giuffrida et al., 2017a; 2017b).

Most of the empirical contributions emphasise the relationships between the adoption of e-commerce and the phenomena of internationalisation. This is often done through econometric analyses aiming to explain the link between technology, internet and e-commerce on one side, and export on the other side, mainly at the country level. Less has been done at the company level.

One of the few and earliest evidences of the relationship between internet and export is provided by Piscitello and Sgobbi (2003) who acknowledge that the diffusion of Internet applications and, more generally, information and communications technologies (ICTs), provides smaller businesses with new tools and opportunities to expand their presence in foreign markets, as both exporters and producers. Indeed, by using e-business, firms may reduce the costs of information-intensive activities, such as communications management and sales and marketing. These opportunities may especially favour the international activities of SMEs by downsizing some of their historical shortcomings when compared with larger businesses. The evidence from SMEs in the Italian industrial districts shows that actual opportunities to transfer the successful district model to the globalised Internet economy are threatened by serious challenges (Piscitello and Sgobbi, 2004).
Freund and Weinhold (2004), using time-series and cross-sectional variations in bilateral trade data, find that the internet positively affects trade across countries, but that the effect decreases depending on the geographical distance between the trading countries.

Likewise, Gómez-Herrera et al. (2014) analyse the impact of geographical distance on the online cross border trade of goods in Europe and investigate the possible drivers and barriers to this phenomenon. They show that e-commerce reduces geographical distance-related trade costs with respect to offline exchanges, while not completely bringing about the so called "death of distance" (Cairncross, 1997). In fact, many other costs emerge in a CBEC context, such as the costs related to language and communications, parcel delivery and online payment systems (GómezHerrera et al., 2014). Similarly, Lendle et al. (2012) use a gravity model to evaluate the effect of e-commerce on trade volumes and costs.

More recently, there is a growing awareness that CBEC is becoming a necessity for companies and should be implemented as a priority to boost international growth (Hsiao et al., 2017; Accenture and AliResearch, 2015). However, although the impact of digitalisation on the internationalisation of firms is a topic that has received attention recently (Alcácer et al., 2016; Von Tulder et al., 2018), the debate as to whether e-commerce is really a facilitator of internationalisation is still open. Some authors state that CBEC helps to reduce costs related to international payments, logistics, and language, and that e-commerce has the potential to facilitate exporting processes (Karavdic and Gregory, 2005; Hameri and Hintsa, 2009; Hsiao et al., 2017). Gómez Herrera et al. (2014), among others, recognise that CBEC entails several barriers and challenges, some of which refer to the traditional liabilities of foreignness (e.g. linguistic and cultural differences), while others are specifically related to e-internationalisation (e.g. e-commerce regulations, compatibility and interoperability between online payment systems). Similarly, Terzi (2011) 
suggests that, despite offering significant opportunities to countries globally, e-commerce is not a synonym for increased international trade. Whether its net effect on global trade will be positive is indeed highly dependent on the nature of the good since, for instance, many products are not tradeable in digital form.

The ambivalent impact of e-commerce as a facilitator of or a further barrier to internationalisation is even more pronounced when considering SMEs, which are traditionally more affected by the liability of foreignness and outsidership due to their "smallness" (Johanson and Vahlne, 2009; Kuivalainen et al., 2012). One of the main points discussed concerning SMEs is that they find it difficult to compete with large transnational companies, which have greater bargaining power with local logistic providers and more advanced skills in exporting (Savrul et al., 2014).

Additionally, Stockdale and Standing (2006) point out the other main inhibitors that prevent SMEs from adopting e-commerce: i) the lack of specific ICT knowledge; ii) uncertainty concerning the investment: firms might be hesitant to invest in a technology like e-commerce due to security issues and the fact that insights gained from data can become obsolete quickly; iii) the lack of resources, as indeed hardware and software costs represent a significant investment for smaller companies. Similarly, Li et al. (2014) find that the limited capabilities and resources of SMEs can be potential obstacles for them. Piscitello and Sgobbi (2004) highlight the fact that the nature of the traded goods has an impact on the adoption of e-commerce by SMEs. Whenever the products have non-standard features requiring direct contact for evaluation, such as in the case of luxury textiles, the internet can be mainly used as a complementary marketing channel, but its evolution into a proper sales channel is often obstructed by the lack of technological competencies. Gessner and Snodgrass (2015) acknowledge that SMEs face substantial barriers when it comes to doing online business across international borders, including differences in customs and duty regimes and tax laws. Although some federal governments are trying to alleviate the impact of such barriers by providing government programmes such as duty-free zones, most often smaller companies do not meet the size requirements in order to benefit from such programmes.

However, other authors support the idea that technology, by reducing the cost of information-intensive activities, such as communication, sales and marketing, provides certain opportunities for SMEs (Brynjolfsson, 1990). Hagsten and Kotnik (2017) find that ICT is to a large extent positively related to the exporting activities of SMEs. However, the key factors that impact the decision to export online and the export intensity are the level of ICT knowledge of the company, previous exporting experience, labour productivity, size and foreign ownership.

Thus, most of the literature seems to suggest that SMEs encounter a complex mix of opportunities and threats posed by both the diffusion of digital technology and the globalisation of markets (Piscitello and Sgobbi, 2003). The main benefits are associated with decreased entry costs and the availability of new and faster sales and communication channels (Lohrke et al., 2006; Morgan-Thomas and Jones, 2009; Martens, 2013). Conversely, the main barriers concern the legal aspects of $\mathrm{CBEC}$, including customs and duty regimes and tax laws (Bieron and Ahmed, 2012; Polanski, 2002; Teltscher, 2002), marketing and branding issues (Guercini and Runfola, 2015) combined with cultural aspects in distant markets (Gefen and Heart, 2006), and logistics issues (Ramanathan et al., 2014; Delfmann et al., 2002; Visser and Nemoto, 2002; Cho et al., 2008).

Other scholars point out that e-commerce adds uncertainty to the already risky process of internationalisation (Atik, 2012); in fact, selling to online customers involves more than setting up a functioning website (Sinkovics et al., 2007).

Investigations concerning the barriers to e-commerce adoption have been conducted for certain countries, such as Sweden and Australia (MacGregor and 
Vrazalic, 2005), India, Malaysia and Iran (Jahanshahi et al., 2013). A significant objective of this paper is to investigate the impediments and the barriers faced by Italian firms regarding the adoption of CBEC by disentangling the specificities associated with digital (vs. traditional) trade, SMEs (vs. large companies) and with certain specific (vs. generic) geographic areas.

\section{The survey}

\section{Sample}

To investigate the opportunities and barriers relating to internationalisation which e-commerce presents, we drew up a survey and sent it to 600 Italian companies operating in the food and beverage and fashion industries, relying on the database of the Digital Export Observatory promoted by the School of Management of Politecnico di Milano. These two sectors were selected because they are typical representatives of "Made in Italy" abroad, and thus likely provide the most attractive types of goods for international consumers. Moreover, food and fashion are among the biggest contributors to Italian export, with a share of $7.6 \%$ and $11.4 \%$ on total exports respectively (ISTAT, 2018). Their combined weight increases to over $50 \%$ of the export of consumer goods.

The Research path consisted of the following phases:

1) Sampling: Out of our population of interest (i.e. Italian companies producing consumer goods in the food and fashion industries), we administered our survey to approximately 600 large companies and SMEs.

2) Design of survey instrument (questionnaire): The survey consists of a few introductory questions, useful to filter responses which match our research purposes. Therefore, preliminary questions were asked to investigate whether the respondent was an exporting company and made use of online tools for this process. If a company already uses e-commerce to (also) export to the USA and China, i.e. our destination countries

\begin{tabular}{|c|c|c|}
\hline \multicolumn{3}{|l|}{ FEATURES OF THE SAMPLE } \\
\hline Item & $\mathrm{N}^{0}$. & $\%$ \\
\hline \multicolumn{3}{|l|}{ Company size } \\
\hline Small (<250 employees) & 45 & 41 \\
\hline Large ( $\geq 250$ employees) & 65 & 59 \\
\hline Total & 110 & 100 \\
\hline \multicolumn{3}{|l|}{ Industry } \\
\hline Fashion & 50 & 45 \\
\hline Food and Beverage & 60 & 55 \\
\hline Total & 110 & 100 \\
\hline \multicolumn{3}{|l|}{ Respondent profile } \\
\hline Export Director/Manager & 35 & 32 \\
\hline Founder/CEO & 8 & 7 \\
\hline Supply Chain \& Operations Director/Manager & 20 & 18 \\
\hline Sales \& Marketing Director/Manager & 30 & 27 \\
\hline IT Director/Manager & 17 & 16 \\
\hline Total & 110 & 100 \\
\hline \multicolumn{3}{|l|}{ Areas served via CBEC* } \\
\hline China & 67 & 61 \\
\hline USA & 75 & 68 \\
\hline Other & 78 & 71 \\
\hline \multicolumn{3}{|c|}{$\begin{array}{l}\text { NOTE: *Each company can select more than one desti- } \\
\text { nation market. } \\
\text { SOURCE: Survey developed by the authors. }\end{array}$} \\
\hline
\end{tabular}

of interest, it is filtered out and the questionnaire terminates. If a company does not export or does so only through "traditional" channels, the survey activates and questions concerning the barriers are displayed.

3) Survey administration and data collection: The survey was sent out to the identified recipients through an online survey administration tool called Opinio.

4) Data preparation: A total of 150 answers (response rate of $25 \%$ ) were received. In this phase, data were cleaned and homogenised. In particular, all missing values, inconsistent or incomplete responses were cleared, leading to a final set of 110 complete responses including both companies adopting CBEC towards the USA and China, and companies using CBEC 


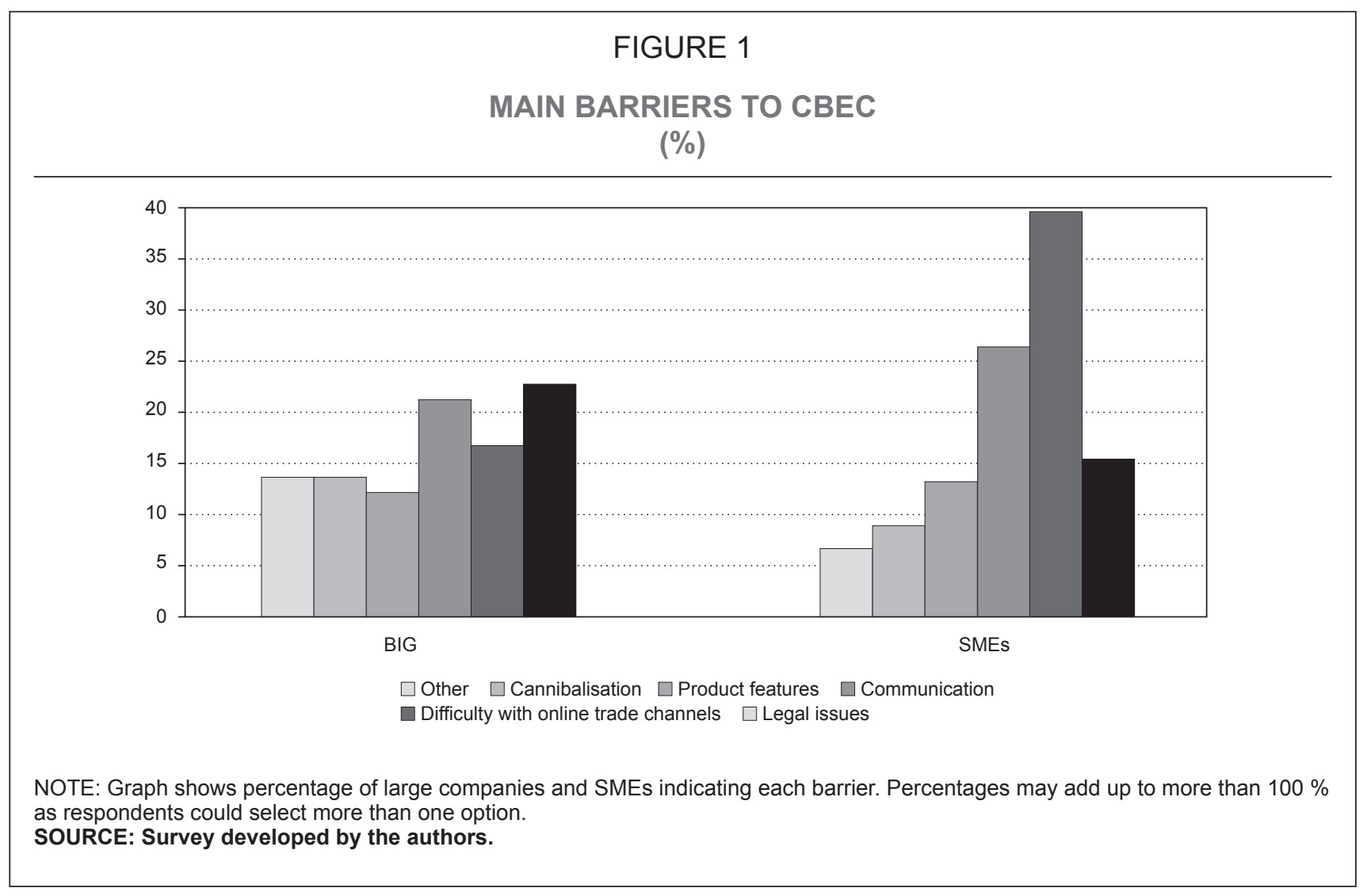

towards other destination markets. The final sample, whose features are summarised in Table 1, consists of both large companies, i.e. companies with at least 250 employees (59 \% of respondents), and SMEs, employing less than 250 people (41\%).

\section{Results}

Responses were analysed by employing particular descriptive statistics and results were interpreted to provide insights regarding the relationship between the adoption of e-commerce and internationalisation for SMEs.

Selling abroad is a rather diffuse practice among food and fashion companies in Italy. However, about half of the exporting companies (48\%) export through traditional channels (e.g. importers, trade agents, wholesalers and retailers), and e-commerce is not largely used to reach foreign countries: just $1 \%$ adopt a pure online strategy to sell abroad while $28 \%$ adopt a different strategy depending on the destination market (i.e. it uses online channels to reach certain countries and exclusively offline channels to reach others). The remaining $23 \%$ adopt a multichannel approach by using both online and offline channels for every destination market. Regarding the main barriers to the adoption of CBEC, distinguishing between SMEs and large companies (Figure 1), SMEs specifically mention: $i$ ) the inability to correctly use available online trade channels ${ }^{1}$ (40\% of respondents); ii) the difficulty of communicating in

\footnotetext{
${ }^{1} \mathrm{~A}$ trade channel represents the instrument through which the sale transaction is performed (it can be the manufacturer's own website, an online retailer, a marketplace, a flash sale website).
} 
FIGURE 2

MAIN BARRIERS TO CBEC TOWARDS CHINA

(\%)

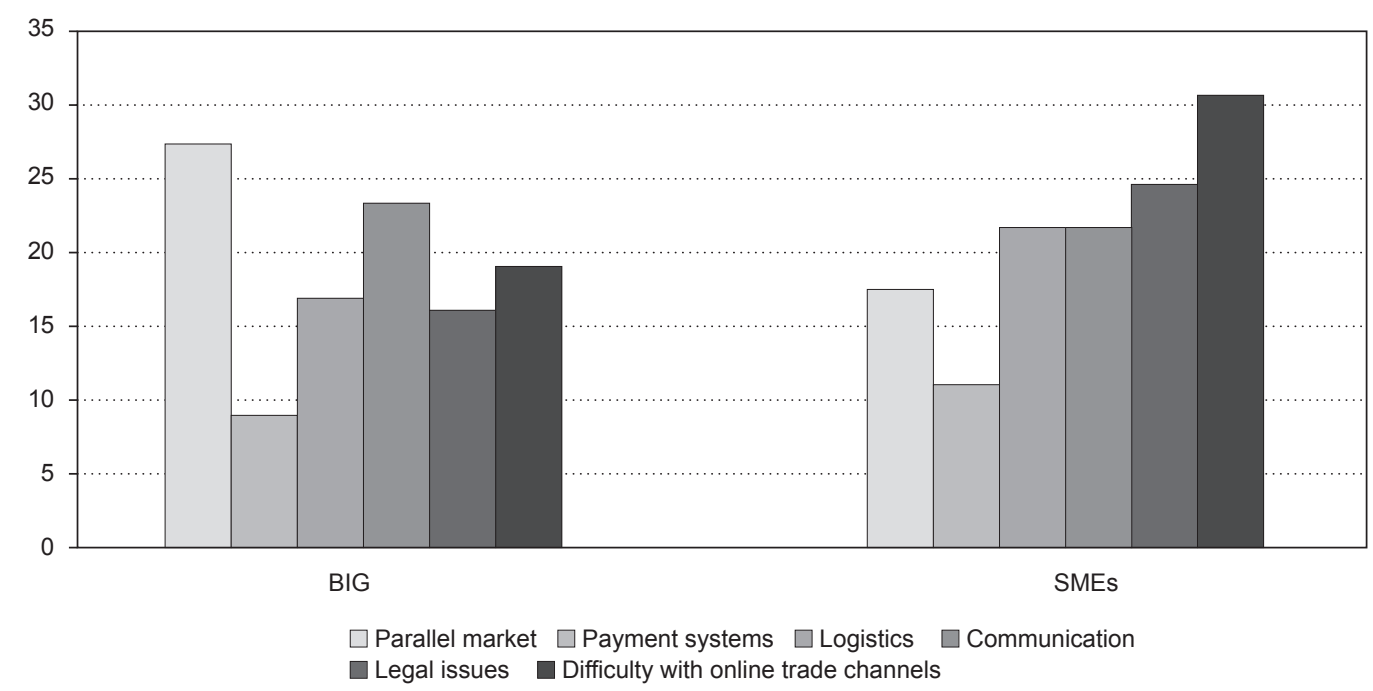

NOTE: Graph shows percentage of companies indicating each barrier. Percentages add up to more than $100 \%$ as respondents could select more than one option.

SOURCE: Survey developed by the authors.

an effective way with international consumers $(27 \%$ of respondents); iii) the complexity relating to compliance with legal requirements (16\%); iv) the constraints posed by specific products, e.g. fresh goods require delivery at a controlled temperature (13\%); v) the risk that online channels could cannibalise traditional channels, i.e. drive away consumers from physical shops thus reducing their sale volumes (9\%).

Conversely, large companies exhibit a different ranking of the same factors. The main obstacle for larger companies is related to the management of legal issues (23\%), followed by the management of online communication activities (22\%). The inability to select and properly manage online trade channels is mentioned by $17 \%$ of companies, while cannibalisation risk is mentioned by $14 \%$ of large companies ( $5 \%$ more than in the case of SMEs).
When distinguishing between destination countries, the barriers to the adoption of CBEC towards China are still inadequate understanding and use of available third-party trade channels, different culture and communication standards, bureaucracy and stringent legal requirements. However, as illustrated in Figure 2, certain new factors are identified, namely different online payment systems, complex logistics, and the existence of a parallel market. SMEs more frequently mention the difficulty of managing online channels in China (31\%), of being compliant with legal requirements (24\%), and of managing logistics (22\%) and communication effectively (22\%). Conversely, larger companies refer more to the parallel market problem. This is most likely due to the higher propensity of customers to buy more famous or prestigious brands, typically owned by large enterprises, via unofficial channels. 


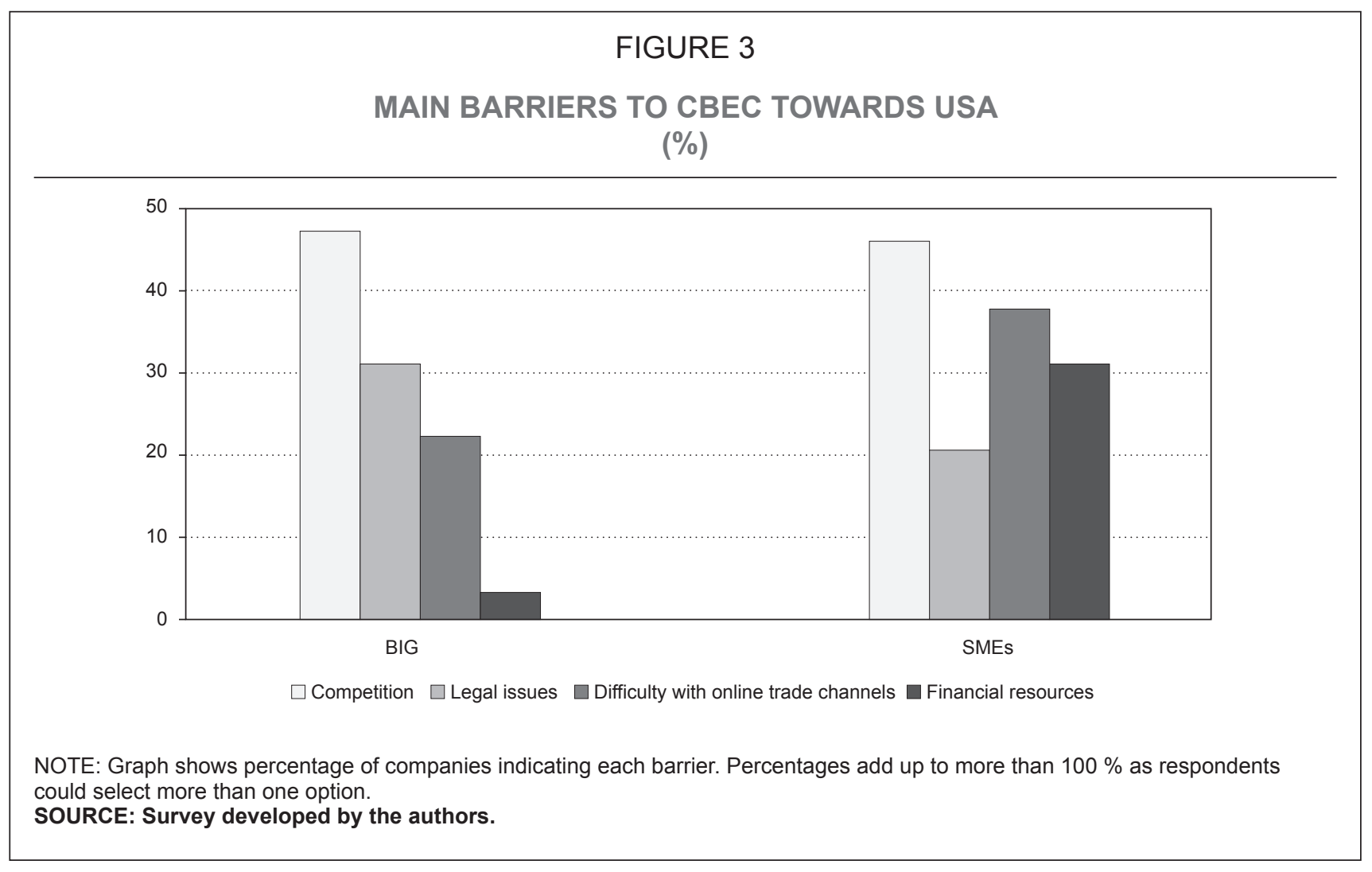

Results change when considering the USA (Figure 3). In fact, both large companies (48 \%) and SMEs (47 \%), perceive the most critical barrier to be the excessive competition with both local companies and other international players already using CBEC. Difficulties in the use of online trade channels (38\%) and legal complexities (20\%) rank second and third for SMEs, while larger companies rank online channel management as less burdensome than legal issues. The need for financial resources is an additional impediment to CBEC towards the USA and is specifically mentioned mainly by SMEs ( $31 \%)$.

\section{Discussion and conclusion}

\section{Discussion of the results}

This study aimed to provide further evidence concerning the main complexities and barriers which often prevent Italian companies from seizing the opportunities offered by CBEC. A survey was conducted in order to derive insights from companies operating in two of the major "Made in Italy" industries, i.e. food and fashion. To summarise, we can observe that the barriers to CBEC most commonly faced by Italian companies in the food and fashion sectors mainly refer to the following different fields: a) trade channels, b) logistics channels, c) legal requirements, d) payment systems, and e) culture and communication. The survey allowed us to identify different types of barriers, i.e. i) offline vs. online barriers; ii) barriers for small vs. large firms; iii) general (i.e. those most commonly faced when exporting online, whatever the destination) vs. specific (i.e. to reach the USA and China) barriers.

As regards the first issue, our results show that some of the barriers are typical of traditional internationalisation processes, e.g. cultural issues, lack of financial resources 
and bureaucracy, while others specifically belong to the e-commerce domain, e.g. managing online trade channels, digital marketing and online payment systems. Regarding the differences between the barriers recognised by SMEs and those recognised by large companies, the former report issues with managing online channels and a lack of financial resources more often than the latter. Finally, as regards the third issue, trade channels and legal requirements are frequently recognised as critical by the surveyed sample regardless of the destination market. The difficulty concerning trade channels might largely derive from the lack of knowledge regarding the existing alternatives and is more frequently mentioned by SMEs than large companies. Legal aspects are also regarded as critical regardless of the geographic area: it is not surprising that legislation is often burdensome. The study also reveals barriers which are specific to the two markets of interest. When considering selling to China, companies, especially large ones, often have concerns regarding the existence of the parallel (or "grey") market. This refers to cases when sold products do not follow official or authorised channels. This practice, despite not being illegal, poses a threat as it may "compete" with official online trade channels. In addition, logistics and payment systems are recognised as particularly complex for the Chinese market. As far as the USA is concerned, an additional barrier emerges, i.e. the market is considered too competitive. Due to its geographical width, it is sometimes difficult to serve the USA market online from a distant country and guarantee an appropriate service level.

\section{Contribution to the literature}

This evidence is important because understanding barriers to the adoption of CBEC is a first step towards shedding light on the reasons why e-commerce has not yet reached its full potential as regards boosting the international business propensity of small and large companies, despite the fact that early studies on this topic predicted an expansion of international business networks associated with e-commerce (de la Torre and Moxon, 2001; Zaheer and Manrakhan, 2001). Thus, our results contribute to the ongoing debate concerning the role of information and communications technologies in international business (see, for instance, Alcácer et al., 2016) by showing how e-commerce does not act as an automatic facilitator of cross-border trade due to the presence of different types of barriers, some of which are specific to the type of export (i.e. digital vs traditional), the size of the firm (SMEs vs. large companies) and the geographic area. As regards the latter, presenting the results regarding CBEC barriers for certain specific destination markets is a distinctive feature of this paper: indeed, whereas most past studies regarding the barriers to CBEC mention general challenges which are faced by companies, considering global markets as a single entity, we show that the type and intensity of barriers can be highly influenced by the features of the target country.

We also contribute to the international logistics and distribution literature, where one of the most debated points in this regard is the mismatch between the growth of the e-commerce market and that of logistics, especially as regards the Chinese context, where e-commerce demand has grown extremely rapidly. Indeed, logistics has become a bottleneck when it comes to further e-commerce development (Hou, 2014) because it has not been able to keep up with this growth rate, hindered by the time needed to develop the necessary infrastructure. In a sense, e-commerce has therefore brought a number of challenges to Chinese logistics which current players have not been able to overcome adequately (Hensher, 2015). Logistics services were largely affected with consequences such as late deliveries, order cancellation by merchants, goods lost in the shipping process, incorrect order fulfilment (Jiao, 2014).

\section{Managerial implications}

Given that -as in the case of traditional tradeforeign companies adopting CBEC are at a 
disadvantage with respect to players established locally, it may be advisable to be physically present in the territory with a combined online and offline strategy in order to reduce the liability of foreignness and outsidership. Of course, this strategy requires greater investment, which is why the lack of sufficient financial resources is listed among the top barriers, especially by SMEs, which therefore should seek significant financial support in order to tackle such a challenge. It is also recommended that SMEs increase their knowledge - which has been limited - concerning trade channels in order to foster their ability to export online to distant countries as well. This knowledge is often offered by service providers and trading companies ready to help manufacturers to better reach international consumers. However, many companies remain unaware of this. Therefore, they rely solely on their own website to perform CBEC, which is often hazardous, given that this website is probably designed to better serve local customers, rather than foreign ones.

As regards the legal burden, without a clear understanding of the correct procedures and requirements which need to be complied with, the CBEC process might take longer and appear more difficult than it actually is. Companies may occasionally require consultancy from legal experts in order to tackle these issues and these are resolvable through appropriate assistance. However, on other occasions legal requirements can represent genuine constraints and prevent companies from being able to access a specific opportunity. This is the case, for instance, with alcoholic beverage producers who find it difficult to sell online to the USA because of restrictions linked to the wine distribution industry in North America. By law, it is not possible for a producer to sell wine directly to an American consumer. Importers and distributors need to intermediate the process, making $\mathrm{B} 2 \mathrm{C}$ e-commerce almost impossible to set up.

Lastly, firms must be aware that certain payment systems for use online may be different from western ones. In China, for instance, the e-payment industry is highly concentrated and dominated by local players who set the standard: there is only one official credit card issuer, i.e. China UnionPay, and foreign companies need to provide this option to Chinese buyers. Also, Alipay is the most common payment platform used for e-commerce in China, therefore Italian retailers need to add it to the available payment options.

\section{Policy implications}

Our results suggest that policy support is essential in order to overcome the barriers to CBEC. On the one hand, policy makers should help firms (especially SMEs) to offset their lack of knowledge concerning trade channels, communications strategies and legal issues by promoting ad hoc training programmes for sales managers, in order to improve their export and e-commerce skills. On the other hand, governments should provide financial support (e.g. in the form of monetary incentives or tax-cuts) to SMEs in order to help them to face the costs associated with a CBEC strategy, given that a lack of financial resources has been suggested as one of the main barriers for these companies.

Moreover, our results suggest that policy interventions should be tailored to a greater extent in order to account for the heterogeneity of barriers arising from the type of firms, industries and geographic areas. In this vein, trade agencies should seek to specialise their skills in order to be more effective in assisting firms to implement their CBEC strategy.

\section{Future developments}

To complement our analysis, we recommend future investigations comparing the barriers to CBEC for companies operating either in different home countries (with respect to Italy) but in the same industries (i.e. F\&B and Fashion), or in the same home country (i.e. Italy) but in other industries (e.g. B2C vs. B2B). Future studies should also better disentangle other firm-level characteristics that affect the barriers 
to the adoption of CBEC apart from size (i.e. SMEs vs. large companies). In addition, studies comparing other destination countries of interest (besides China and the US) are encouraged as a follow-up to our preliminary study, which is part of a larger research project to be carried on in the future within the Digital Export Observatory. In particular, the authors also intend to strengthen the empirical basis by enlarging the surveyed sample and by employing more advanced methodologies in order to investigate the dynamics underlying CBEC in greater depth. Indeed, we are confident that, given a reinforcement of the empirical investigation, additional and more detailed insights can be derived in order to understand how the impediments to CBEC can be overcome by adopting tools and developing adequate strategies that help to boost this attractive, yet complex, phenomenon.

\section{Bibliographic references}

Accenture, \& AliResearch (2015). Global Cross Border B2C e-Commerce Market 2020. Report.

Ahlert, D., Blut, M., \& Evanschitzky, H. (2010). Current status and future evolution of retail formats. In Retailing in the 21st Century, (pp. 337-356). Berlin, Heidelberg: Springer.

Alcácer, J., Cantwell, J., \& Piscitello, L. (2016). Internationalisation in the information age: a new era for places, firms and international business networks? Journal of International Business Studies, 47, 499-512.

Atik, A. (2012). A Strategic Investment Decision: "Internationalization of SMEs": A Multiple Appraisal Approach and Illustration with a Case Study. I-Business, 4(2), 146.

Bieron, B., \& Ahmed, U. (2012). Regulating e-commerce through international policy: Understanding the international trade law issues of e-commerce. Journal of World Trade, 46(3), 545-570.

Brynjolfsson, E. (1990). Information technology and economic organization. Massachusetts Institute of Technology. Boston.

Cairncross, F. (1997). The Death of Distance. How the Communications Revolution will Change Our Lives. Orion Business Books. London.

Cho, J. J., Ozment, J., \& Sink, H. (2008). Logistics capability, logistics outsourcing and firm performance in an e-commerce market. International journal of physical distribution \& logistics management, 38(5), 336-359.
De la Torre, J., \& Moxon, R. (2001). E-commerce and global business: The impact of the information and communication technology revolution on the conduct of international business. Journal of International Business Studies, 32(4), 617-639.

Delfmann, W., Albers, S., \& Gehring, M. (2002). The impact of electronic commerce on logistics service providers. International Journal of Physical Distribution \& Logistics Management, 32(3), 203-222.

Digital Export Observatory (2019). Export digitale, quanta strada c'è da fare! Research Report, March, 2019. Milan: School of Management of Politecnico di Milano.

Fariselli, P., Oughton, C., Picory, C., \& Sugden, R. (1999). Electronic commerce and the future for SMEs in a global market-place: Networking and public policies. Small Business Economics, 12(3), 261-275.

Forrester, (2018). Forecast View Global e-Commerce Snapshot, [report].

Freund, C. L., \& Weinhold, D. (2004). The effect of the Internet on international trade. Journal of international economics, 62(1), 171-189.

Gefen, D., \& Heart, T. H. (2006). On the need to include national culture as a central issue in e-commerce trust beliefs. Journal of Global Information Management, 14(4), 1-29.

Gessner, G. H., \& Snodgrass, C. R. (2015). Designing e-commerce cross-border distribution networks for small and medium-size enterprises incorporating Canadian and US trade incentive programs. Research in Transportation Business \& Management, 16, 84-94.

Giuffrida, M., Mangiaracina, R., Perego, A., \& Tumino, A. (2017a). Cross-border B2C e-commerce to Greater China and the role of logistics: a literature review. International Journal of Physical Distribution \& Logistics Management, 47(9), 772-795.

Giuffrida, M., Mangiaracina, R., Perego, A., \& Tumino, A. (2017b). Logistics Solutions to Support Cross Border E-Commerce towards China: The Case of the Apparel Industry. In R. Rinaldi, R. Bandinelli (Eds.), Business Models and ICT Technologies for the Fashion Supply Chain. Lecture Notes in Electrical Engineering, 413, (pp. 163-177). Cham: Springer.

Gómez-Herrera, E., Martens, B., \& Turlea, G. (2014). The drivers and impediments for cross-border e-commerce in the EU. Information Economics and Policy, 28, 83-96.

Guercini, S., \& Runfola, A. (2015). Internationalisation through E-Commerce. The Case of MultiBrand Luxury Retailers in the Fashion Industry. In Barbara Stöttinger, Bodo B. Schlegelmilch, Shaoming Zou (Eds.), International Marketing in the Fast Changing World, Advances in International Marketing, 26, (pp. 15-31). Emerald Group Publishing Limited. 
Hagsten, E., \& Kotnik, P. (2017). ICT as facilitator of internationalisation in small-and medium-sized firms. Small Business Economics, 48(2), 431-446.

Hameri, A. P, \& Hintsa, J. (2009). Assessing the drivers of change for cross-border supply chains. International Journal of Physical Distribution \& Logistics Management, 39(9), 741-761.

Hensher, D. A., Zhang, Z., \& Rose, J. (2015). Transport and logistics challenges for China: Drivers of growth, and bottlenecks constraining development. Road \& Transport Research: A Journal of Australian and New Zealand Research and Practice, 24(2), 32-41.

Hou, X. F. (2014). Analysis on the situation of China's E-commerce logistics. Advanced Materials Research, 926-930, 3750-3753.

Hsiao, Y. H., Chen, M. C., \& Liao, W. C. (2017). Logistics service design for cross-border E-commerce using Kansei engineering with text-mining-based online content analysis. Telematics and Informatics, 34(4), 284-302.

ISTAT (2018), Commercio con l'estero e prezzi all'import dei prodotti industriali. Available at https://www.istat.it/it/archivio/223758, accessed December 19, 2018.

Jahanshahi, A. A., Zhang, S. X., \& Brem, A. (2013). E-commerce for SMEs: Empirical insights from three countries. Journal of Small Business and Enterprise Development, 20(4), 849-865.

Jiao, Z., (2014). Development of E-Commerce Logistics in China. In B. Liu et al. (Eds.), Contemporary Logistics in China. Consolidation and deepening. Springer.

Johanson, J., \& Vahlne, J. E. (2009). The Uppsala internationalization process model revisited: From liability of foreignness to liability of outsidership. Journal of international business studies, 40(9), 1411-1431.

Karavdic, M., \& Gregory, G. (2005). Integrating e-commerce into existing export marketing theories: A contingency model. Marketing Theory, 5(1), 75-104.

Kshetri, N. (2007). Barriers to e-commerce and competitive business models in developing countries: A case study. Electronic Commerce Research and Applications, 6(4), 443-452.

Kuivalainen, O., Sundqvist, S., Saarenketo, S., \& McNaughton, R. (2012). Internationalisation patterns of small and medium-sized enterprises. International Marketing Review, 29(5), 448-465.

Lendle, A., Olarreaga, M., Schropp, S., \& Vezina, P. L. (2012). There goes gravity: how eBay reduces trade costs. CEPR discussion article 9094.

Li, H., Mäntymäki, M., \& Zhang, X., (Eds.) (2014). Digital Services and Information Intelligence, 445. Berlin, Heidelberg: Springer Berlin, Heidelberg.

Lohrke, F. T., Franklin, G. M., \& Frownfelter-Lohrke, C. (2006). The internet as an information conduit: A transaction cost analysis model of US SME internet use. International Small Business Journal, 24(2), 159-178.

MacGregor, R. C., \& Vrazalic, L. (2005). A basic model of electronic commerce adoption barriers: A study of regional small businesses in Sweden and Australia. Journal of small business and enterprise development, 12(4), 510-527.

Martens, B. (2013). What Does Economic Research Tell Us About Cross-Border E-Commerce in the EU Digital Single Market? Publications Office of the European Union. Luxembourg.

Morgan-Thomas, A., \& Bridgewater, S. (2004). Internet and exporting: Determinants of success in virtual export channels. International Marketing Review, 21(4/5), 393-408.

Morgan-Thomas, A., \& Jones, M. V. (2009). Post-entry internationalization dynamics: differences between SMEs in the development speed of their international sales. International Small Business Journal, 27(1), 71-97.

Piscitello, L., \& Sgobbi, F. (2003). SMEs in the new economy-evidence from selected Italian districts. Competition \& Change, 7(1), 61-78.

Piscitello, L., \& Sgobbi, F. (2004). Globalisation, E-Business and SMEs: Evidence from the Italian District of Prato. Small Business Economics, 22(5), 333-347.

Polanski, P. P. (2002). A new approach to regulating internet commerce: Custom as a source of electronic commerce law. Electronic Communication Law Review, 9(3), 165-205.

Premazzi, K., Castaldo, S., Grosso, M., \& Hofacker, C. (2010). Supporting retailers to exploit online settings for internationalisation: The different role of trust and compensation. Journal of Retailing and Consumer Services, 17(3), 229-240.

Qin, Z., Shundong, L., Yiķ, H., Jinchun, D., Lixiang, Y., \& Jun, Q. (2009). E-commerce and International Trade. In Z. Qin (Ed), Introduction to e-commerce, (pp. 3-76). Berlin, Heidelberg: Springer.

Quelch, J. A., \& Klein, L. R. (1996). The Internet and International Marketing. Sloan Management Review, 37(3), 60-75.

Ramanathan, R., George, J., \& Ramanathan, U. (2014). The role of logistics in E-commerce transactions: An exploratory study of customer feedback and risk. In Supply Chain Strategies, Issues and Models, (pp. 221-233). London: Springer.

Savrul, M., Incekara, A., \& Sener, S. (2014). The Potential of E-commerce for SMEs in a Globalizing Business Environment. Procedia-Social and Behavioral Sciences, 150, 35-45.

Sinkovics, R. R., Yamin, M., \& Hossinger, M. (2007). Cultural adaptation in cross border e-commerce: a study of German Companies. Journal of Electronic Commerce Research, 8(4), 221-235.

Stockdale, R., \& Standing, C. (2006). A classification model to support SME e-commerce adoption initiatives. Journal 
of Small Business and Enterprise Development, 13(3), 381-394.

Teltscher, S. (2002). Electronic commerce and development: Fiscal implications of digitized goods trading. World Development, 30(7), 1137-1158.

Terzi, N. (2011). The impact of e-commerce on international trade and employment. Procedia Social and Behavioral Sciences, 24, 745-753.

Visser, J. G. S. N., \& Nemoto, T. (2002). E-commerce and the consequences for freight transport. In E. Taniguchi, \& R. G. Thompson (Eds.), Innovations in freight transport, (pp. 165-193). Boston: WIT press.

Von Tulder, R., Verbeke, A., \& Piscitello, L. (2018). International Business in the Information and Digital Age. Prog- ress in International Business Research, 13. Emerald Publishing.

Walczuch, R., Van Braven, G., \& Lundgren, H. (2000). Internet Adoption Barriers for Small Firms in the Netherlands. European Management Journal, 18(5), 561-572.

World Trade Organisation (WTO) (2018). Exports of goods and services (\% of GDP). Available at http://data.worldbank.org/indicator/NE.EXP.GNFS.ZS, accessed July 17, 2019.

Zaheer, S., \& Manrakhan, S. (2001). Concentration and dispersion in global industries: Remote electronic access and the location of economic activities. Journal of International Business Studies, 32(4), 667-686. 


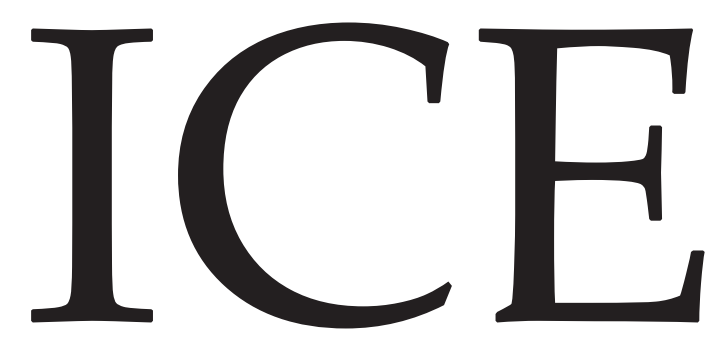

MINISTERIO DE INDUSTRIA, COMERCIO Y TURISMO

INFORMACIÓN COMERCIAL ESPAÑOLA

Secretaría de Estado de Comercio

\section{Últimos números publicados}

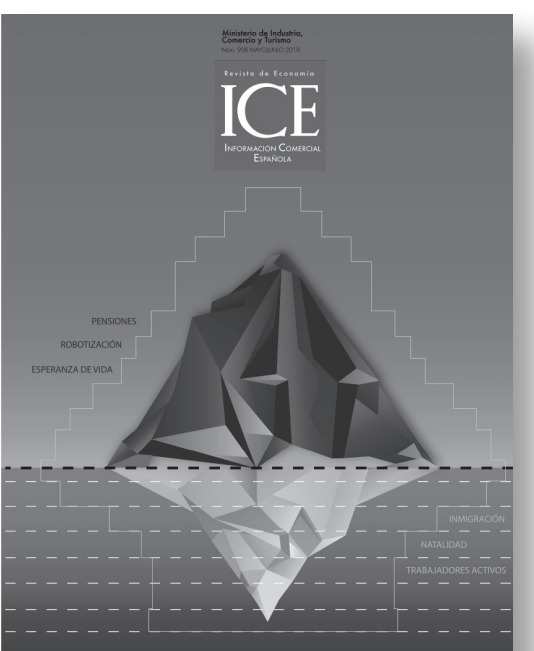

Espania ante el reto demográfico

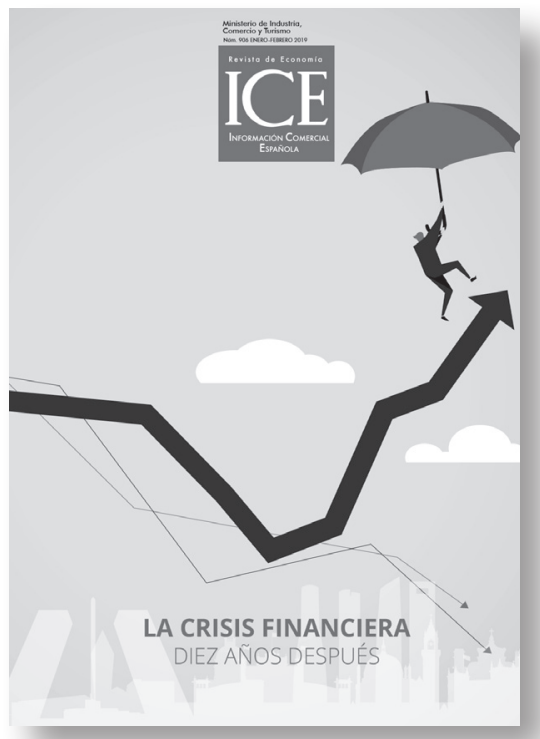

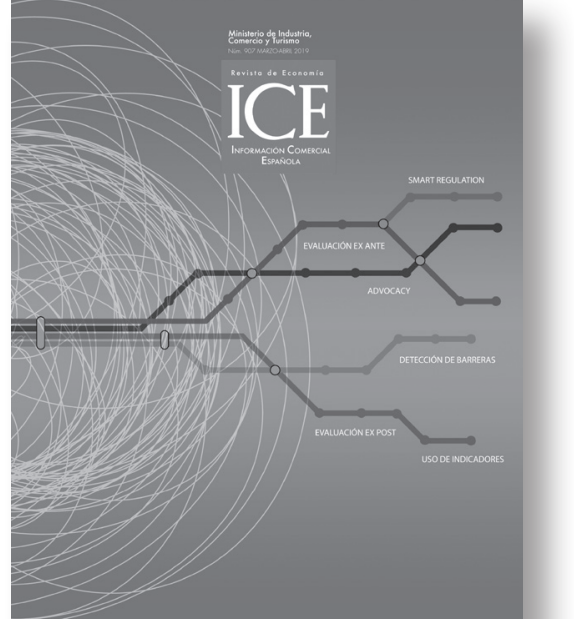

La Mejora de la Regulación

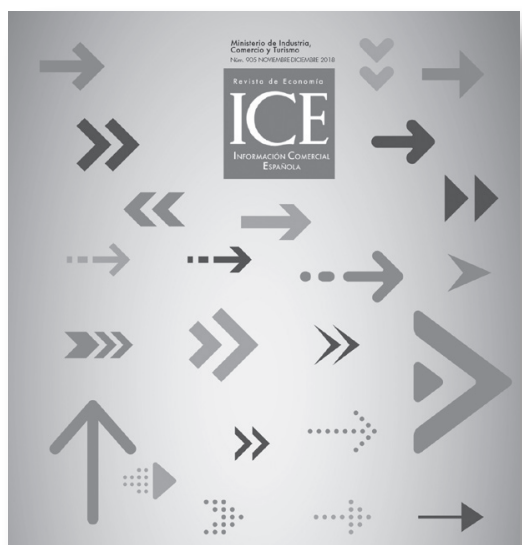

RECULACIÓN DE MERCADOS Y COMPETENCIA

$\because \because>0>\lambda$

Librería virtual y venta: www.mincotur.es

Panamá, 1. 28046 Madrid.

Telf. 913495129

www.revistasice.com

CentroPublicaciones@mincotur.es 